\title{
Northanger Abbey: Jane Austen's Connexion with Ann Radcliffe and the Gothic
}

\author{
Cynthia Whissell \\ Laurentian University
}

*Corresponding Author: Cynthia Whissell, Laurentian University. Email: cwhissell@laurentian.ca

\begin{abstract}
Austen's novel Northanger Abbey is often classed as a parody of the gothic novels of the late $18^{\text {th }}$ century and it refers directly to Radcliffe's The Mysteries of Udolpho. The emotion in the language of the two works (Udolpho, Northanger) is compared with the help of the Dictionary of Affect in Language, whose outcomes are also employed to depict Aristotelian plot development in terms of fluctuations in fortune and misfortune in each novel. The two novels differ stylistically (most notably in total length and sentence length), and also emotionally. Udolpho is significantly less pleasant, significantly less active, and significantly more concrete in its language than Northanger ( $t$ tests, $p<.001)$. Plots, modeled with polynomial regressions ( $p<.001)$, indicate that there are several emotional turning points in each novel. These are labeled and described. Udolpho is characterized by a happy ending while Northanger displays a relatively unhappy ending. In an unexpected result, differences which suggest a two-part composition are noted between early (1-16) and later (17-31) chapters of Northanger Abbey.
\end{abstract}

Ann Radcliffe and Jane Austen each wrote a "gothic" novel near the end of the $18^{\text {th }}$ century. The Mysteries of Udolpho was published in 1794 and Northanger Abbey, written beginning in the 1790s, was published after Austen's death in 1818. Each novel tells the tale of an isolated young woman at the mercy of a domineering older male figure in a grand and frightening mansion. Each young heroine faces her fears, finds the most egregious of them to be groundless, and marries the young man of her choice. Northanger makes several direct references to Udolpho, ${ }^{1}$ and the connection between the two novels has been noted by authors treating the gothic genre (e.g., Skinner, 2013; Wallace, 1988). Udolpho was an extremely successful novel and it was widely read in its day (Howard, 2001); Northanger continues to be widely read today as a part of the Austen opus. According to the Google Ngram Viewer ${ }^{\circledR}$, which searches millions of books for the occurrence of words, phrases, or titles, The Mysteries of Udolpho is mentioned more frequently in publications issued between the novel's first appearance in 1794 and 1872, while Northanger Abbey is mentioned more frequently from 1887 onwards. ${ }^{2}$

It is frequently suggested that Udolpho is a gothic masterpiece while Northanger is a parody of the genre (e.g., Lenckos, 2010; Rehn, 2014). Parody involves the comic retelling and transformation of a text in a manner designed to promote critical thinking, both about the parodied text and about the parody itself (Hannoosh, 1989). Benét's Reader's Encyclopedia (1987, p. 738) defines parody as "a comic or satirical imitation of a piece of writing, exaggerating its style and content, and playing especially on any weakness in the structure or meaning of the original." Word ${ }^{\circledR}$ and Google ${ }^{\circledR}$ offer "mockery" as a synonym of "parody." Was mockery Austen's main aim in writing Northanger Abbey? Freeman (1963) suggests that parody might focus on ridiculing a well-known work, or that it might instead take a "positive and constructive" approach that creates new meaning by reading an existing work in a creative manner (p. 307). Gothic romances deal with emotional settings and emotional conflicts (isolated maidens, grand vistas, forbidding castles, ghosts), often dwelling on them to an extreme degree. If Udolpho is a gothic masterpiece, and Northanger is a parody of the

\footnotetext{
${ }^{1}$ There are a total of 18 references to Udolpho in Northanger, mainly in conversations held between Catherine Moreland and Isabella Thorpe, Catherine and John Thorpe, and Catherine and Henry Tilney.

2 The Ngram Viewer can be found at https://books.google.com/ngrams/graph?content\&direct_url and an explanation for its use at https://books.google.com/ngrams/info.
} 
genre, then they should differ in terms of their emotional structure and their use of emotional words. The parody should dwell less on fearful situations than the true gothic novel, and have a crisper writing style. In contrast, the gothic novel should wallow in its negative emotions. This research employs a quantitative technique called the Dictionary of Affect in Language (Whissell, 2009) to score the words in the two novels for their emotional impact by quantifying the words' pleasantness, activation, and imagery. Scores on the pleasantness dimension are then used to outline the plot of each novel in terms of variations in fortune across time.

It is relatively easy for even the most inexperienced reader to appreciate some of the qualitative differences between Udolpho and Northanger. Sample passages from the climax of each novel are included in Table 1. Quantitative analyses of the two novels will produce supplementary evidence that can be employed in a triangulation of results - one where different methodologies are brought to bear on the same material with the aim of establishing more far-reaching conclusions. As well, the quantitative representation of plot structure is a relatively new approach to the analysis of literature (e.g., Whissell, 2017), and it is expected to disclose the manner in which emotions change from moment to moment as the story in each novel unfolds.

Table1. Emotionally scored excerpts from the two novels with examples of extreme words (as scored by the Dictionary of Affect in Language)

Excerpt from the Beginning of Volume 3, Chapter I of Mysteries of Udolpho

He [Barnardine] requested, that Emily would meet him, unattended, on the terrace, at a little after midnight, when he himself would lead her to the place he had promised; a proposal, from which she immediately shrunk, for a thousand vague fears darted athwart her mind, such as had tormented her on the preceding night, and which she neither knew how to trust, or to dismiss. It frequently occurred to her, that Barnardine might have deceived her, concerning Madame Montoni, whose murderer, perhaps, he really was; and that he had deceived her by order of Montoni, the more easily to draw her into some of the desperate designs of the latter.

Pleasantness: 46.0 Activation: 49.0, Imagery: 45.3, Rate of Word Matching: 87\%; Words per Sentence: 55

\begin{tabular}{|c|c|c|}
\hline Sample Pleasant Words & Sample Active Words & Sample Concrete Words \\
\hline Easily & Desperate & Little \\
Meet & Frequently & Madame \\
Proposal & Lead & Midnight \\
Thousand & Murderer & Night \\
Trust & Promised & Place \\
\hline Sample Unpleasant Words & Sample Passive Words & Sample Abstract Words \\
\hline Desperate & Knew & Concerning \\
Fear & Latter & Perhaps \\
Murderer & Might & Preceding \\
Preceding & Perhaps & Promised \\
Vague & Place & Really \\
\hline
\end{tabular}

Excerpt from the end of chapter 23 of Northanger Abbey

In the high-arched passage, paved with stone, which already she had trodden with peculiar awe, she well remembered the doors of which the general had given no account. To what might not those doors lead? In support of the plausibility of this conjecture, it further occurred to her that the forbidden gallery, in which lay the apartments of the unfortunate Mrs. Tilney, must be, as certainly as her memory could guide her, exactly over this suspected range of cells, and the staircase by the side of those apartments of which she had caught a transient glimpse, communicating by some secret means with those cells, might well have favoured the barbarous proceedings of her husband. Down that staircase she had perhaps been conveyed in a state of well-prepared insensibility!

Pleasantness: 49.3, Activation: 49.0, Imagery: 46.0, Rate of Word Matching: 90\%, Words per Sentence 32. 


\begin{tabular}{|c|c|c|}
\hline & Sample Active Words & Sample Concrete Words \\
\hline Sample Pleasant Words & Caught & Apartments \\
Guide & Forbidden & Arched \\
High & No & Doors \\
Husband & Lead & Stone \\
Support & Must & Side \\
Well & Sample Passive Words & Sample Abstract Words \\
\hline Sample Unpleasant Words & Doors & Certainly \\
\hline Forbidden & Exactly & Must \\
Peculiar & Gallery & No \\
No & Means & Proceedings \\
Suspected & Range & What \\
Unfortunate & & \\
\hline
\end{tabular}

\section{DiCTIONARY OF AFFECT}

The Dictionary of Affect contains a list of rated words (Whissell, 2009). It was created with the aid of several hundred volunteers who looked at individual words (no context was provided) and rated each word in terms of how pleasant is seemed, how active it seemed, and how easy it was to form a mental picture of the word. The dimension tapped by the first two ratings is face valid; the last rating, imagery, is meant to assess the concreteness of words. Concrete words (such as "table") are rated highly on this dimension, while abstract ones (such as "continuity") receive low scores because they are difficult to envision. The Dictionary lists the average rating provided by volunteers for 8742 words on each of the three rating dimensions. By employing the average in its applications, the Dictionary discounts individual differences in reactions to particular words. An example of such differences is the case where a person with a spider phobia provides a much lower pleasantness score for the word "spider" than most other people. The Dictionary also discounts differences among multiple word meanings. For example, "ride" could be a verb or a noun, but in the Dictionary it only has one entry and only one set of scores is associated with the word. At the level of single words the Dictionary of Affect is not a precise instrument, but at the level of thousands of words it provides a very accurate picture of the emotionality underlying texts (Whissell, 2009).

When novels are scored by the Dictionary of Affect, every word in the text is matched to the list of rated words. If a match is found, the three scores for that word are input into a file and considered to be part of the emotional information relevant to the text. The entire text is described in terms of averages taken over all scored words for each rated dimension. An example of this application is provided in Table 1 which contains excerpts from Radcliffe's and Austen's novels. The excerpts were taken from the climax of each novel, where each heroine is experiencing her greatest fears and difficulties. The overall Dictionary scores for each excerpt are reported below it. The scale employed has an average of 50: natural English texts tend to yield scores close to 50 for each of the dimensions. The Udolpho excerpt is unpleasant (it has a pleasantness average of 46, somewhat below 50), and it is run-of-the-mill with respect to activation (this average was 49 , or quite close to 50). With an imagery value of 45 , the text is quite abstract. $87 \%$ of all the words in the passage have matches in the Dictionary of Affect. Some examples of extreme words are provided in Table 1. These words all have scores of 60 or more (high end) or 40 or less (low end) on the relevant dimension. The volunteers who created the Dictionary indicated that "easily" and "trust" were pleasant words while "fear" and "murderer" were unpleasant ones. "Desperate" and "frequently" were seen as active words while "might" and "perhaps" were regarded as passive ones. Although "night" and "Madame" were easy to envision and received high imagery scores, "concerning" and "perhaps" were difficult to picture and received low imagery scores.

The Northanger excerpt is of almost average pleasantness (49), and activation (49). Its imagery score is similar to that of the Udolpho excerpt (46), which suggests that both samples are quite abstract in their language. Examples of words from the Northanger excerpt scoring high and low on each dimension are also provided in the table. $90 \%$ of the words in the Northanger excerpt were matched and scored by the Dictionary. A reading of the two excerpts provides a brief introduction to the style of the two authors. The longer sentences employed by Radcliffe are quite obvious, as is Austen's more concise approach to writing. The two complete novels were treated in the manner exemplified in Table 1. 


\section{Plot Structure}

Plots can, of course, be described in terms of the actions that move a story forward. They can also be described in terms of what Aristotle ${ }^{3}$ called "fortune." According to Aristotle, a plot is created when fortune rises or falls within a text. In this research the pleasantness of words is employed to represent fortune. When "fortunate" or good things are happening within the story-line, the author employs many pleasant words to describe them and the relevant section of the text receives high scores for pleasantness (above 50, as measured by the Dictionary of Affect). When "unfortunate" or bad things happen, the author employs many unpleasant words (ones with low pleasantness scores), and the relevant segment of text has low scores for pleasantness (below 50). As fortune rises and falls across the story-line, the pleasantness of the text also rises and falls. The shape of the resulting curve $i$ s the emotional plot of the text.

Plots are represented by the line relating pleasantness to the passage of time within the text. Word number or chapter number, going from first to last, can both be used to represent time. In this research, plots are mathematically modeled in order to smooth them and describe them better. Modeling is accomplished with the help of a polynomial regression formula. The resulting model presents a line that rises and falls in pleasantness smoothly across the novel. An example of a modeled plot is offered in Figure 1 for the sentence "I love birthday parties, but this year I was very sad because it made me remember the death of a friend who lost the battle against cancer." There is an obvious transition, within this sentence of 27 words, from more pleasant words (love, birthday, parties) to less pleasant words (sad, death, cancer). When this transition was modeled with a third order polynomial regression, it was represented in terms of the descending line in Figure 1. This is a tragic plot: it begins at a pleasant level (above 100) and ends at an unpleasant one (close to 0). Modeling similar to that employed in Figure 1 was applied to both Udolpho and Northanger to examine the ways in which good and bad fortune (high and low pleasantness) define their plots.

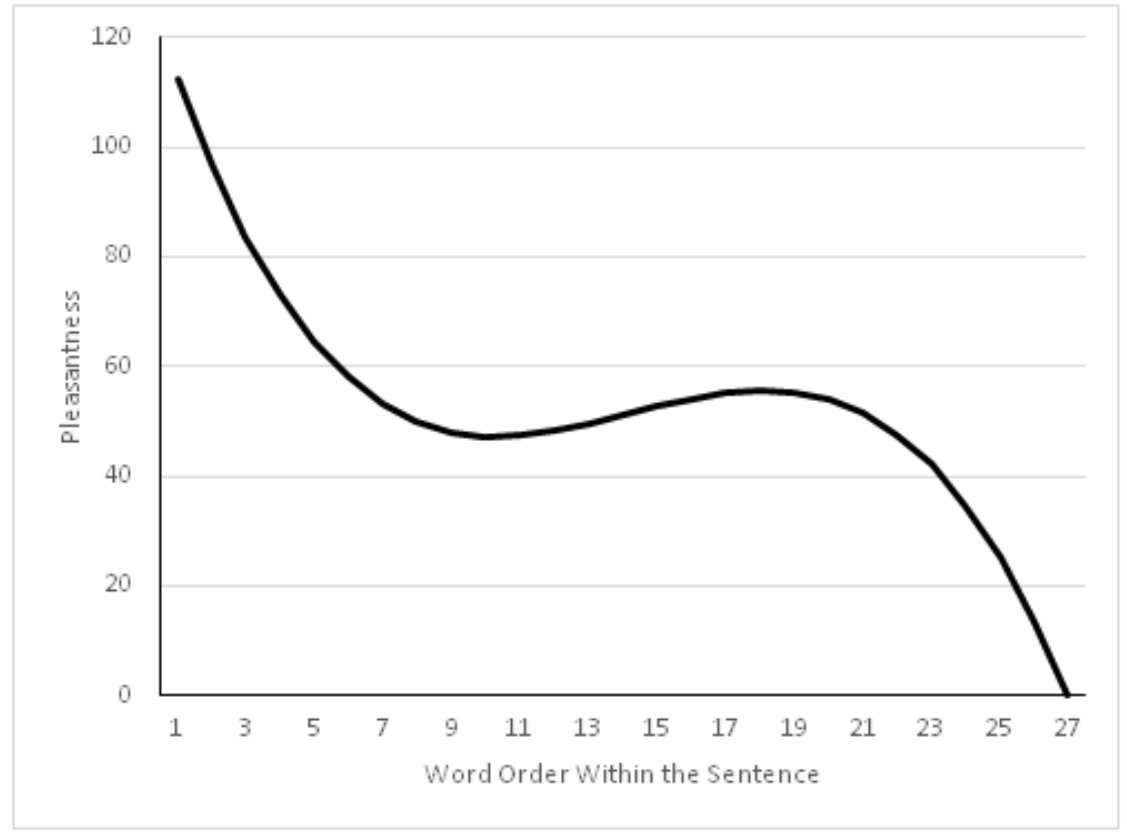

Figure1. Plot for a single sentence $e^{l}$ modeled on the basis of a $3^{\text {rd }}$ order polynomial regression

${ }^{1}$ The sentence modeled was "I love birthday parties, but this year I was very sad because it made me remember the death of a friend, who lost the battle against cancer,"

\section{Method}

The texts for the two novels (files pg3268 and pg121) were downloaded from Project Gutenberg in 2016. An SPSS program written by the author was used to match all the words in each novel to the Dictionary of Affect. Dictionary ratings were identified and imported into a computer file for 255,650 or $87 \%$ of the words in Udolpho and 70,700 or $90 \%$ of those in Northanger.

\footnotetext{
${ }^{3}$ Sections VII and XIII of the Butcher translation of Aristotle's Poetics include discussions of fortune: http://classics.mit.edu/Aristotle/poetics.1.1.html.
} 


\section{RESULTS AND DISCUSSION}

\section{Comparing the Style and Emotionality of the Two Novels}

The two novels differ in several ways. Udolpho is by far the longer novel, being roughly three times as long as Northanger. Radcliffe employed longer sentences than Austen: sentence length is 32.5 words per sentence for Udolpho and 23.3 for Northanger. When it comes to emotionality, Northanger is more pleasant and Udolpho more unpleasant (means of 49.26, 47.78; $t_{326348}=16.00, p<.001$ ). Northanger also has a higher mean for activation than Udolpho which is more passive (48.97, 48.21; $\left.t_{326348}=9.05, p<.001\right)$. Udolpho has the higher mean for imagery and therefore employs more concrete words than Northanger whose language is more abstract (means of 47.30, 45.96, $t_{326348}=8.93, p<.001$ ).

It should be noted that the differences between the novels are not gigantic, involving, as they do, one or two points on a scale that has a range of over 100 points and standard deviations of the order of 20 . This is a fairly typical result for studies of natural language. A single sentence can contain a wide range of word scores for pleasantness, activation, and imagery (as, for example, the sentence in Figure 1 does), and this great variability leads to smaller differences between sources of natural language. One would probably not be able to look at a single word or sentence and decide which of the two novels it belonged to on the basis of its emotionality. However, results indicate that one novel, as a whole, tends to employ more words of a certain type than the other. In this case the gothic masterpiece (Radcliffe's Mysteries of Udolpho) employs fewer pleasant words and more unpleasant ones, it employs fewer active words and more passive ones, and it employs more words that are concrete and easy to envision rather than abstract ones. Radcliffe's novel has a generally sad (unpleasant, passive) mood and it involves extensive and highly imaged descriptions of both scenery and the gothic edifice. In contrast, the parody/mockery of the gothic (Austen's Northanger Abbey) employs more pleasant words, more active words, and more abstract words. The gothic novel is more drawn out (longer), as are its sentences (also longer). The parody is more brisk and to the point. It is happier in mood overall, and crisper in style, and it deals more with thoughts and feelings than with things and actions.

\section{Comparing the Plots of the Two Novels}

In plot development, time was represented by word order (the first word in the novel represents the beginning and the last the end of the plot). Word order was standardized and then raised to the second, third, fourth, fifth, and sixth powers. The resulting terms were used as predictors of pleasantness in a $6^{\text {th }}$ order polynomial linear regression. ${ }^{4}$ The aim of the regression was to predict how pleasant a word would be on the basis of its position within the story. The overall regression for Udolpho was significant $(p<.001)$ as were all individual predictors in the formula except for word number itself $(p<.02) . R$ was $.031 .^{5}$ The predicted pleasantness average for each chapter of Udolpho is plotted in the first half of Figure 2. The overall regression for Northanger was significant $(\mathrm{p}<.001) . R$ was .043 , and all predictors except for the fifth power of number were significant $(p<.02){ }^{6}$ The predicted pleasantness average for each chapter of Northanger is plotted in the second half of Figure 2. Regression analyses confirm that the plots offered in Figure 2 do indeed represent the data, even though they exercise a significant smoothing function upon it. Word to word variations are overlooked in favour of trends of rising and falling pleasantness that characterise various portions of the novel. The greater pleasantness of Northanger, mentioned in the previous section, is obvious in Figure 2 because the plot for this novel is much higher in the pleasantness range than that for Udolpho - so much so that Northanger seems to float above Udolpho. A verbal summary of the novels' plots is offered in Table 2.

\footnotetext{
${ }^{4}$ The $6^{\text {th }}$ order regression was chosen because the inclusion of further terms did not greatly improve prediction.

${ }^{5}$ For Udolpho, the standardized formula was Pleasantness $=.004 * \mathrm{n}+.166 * \mathrm{n}^{2}-.054 * \mathrm{n}^{3}-.308 * \mathrm{n}^{4}+.038 * \mathrm{n}^{5}+$ $.162 * \mathrm{n}^{6}$, where $\mathrm{n}$ represents standardized word order.

${ }^{6}$ For Northanger, the standardized formula was Pleasantness $=-.084 * n-.186 * n^{2}+.014 * n^{3}+.482 * n^{4}-.050 * n^{5}-$ $.301 * n^{6}$
} 
Table2. Plot summaries of the two novels

\begin{tabular}{l} 
Mysteries of Udolpho \\
This novel is set in the late 1500s. Emily St. Aubert, only child of a once-rich family, loses her mother to \\
illness, travels through Europe with her father (lots of travelogue scenes included), and meets Valancourt, her \\
love interest. Her father becomes ill and dies. Emily is then forced to live with her guardian, an aunt (Mme \\
Cheron) and Mme's husband (Montoni). Montoni wishes to marry Emily off to his own advantage, and to \\
ensure that Mme Cheron leaves her no property. Emily remains true to Valancourt and avoids marriage and \\
kidnapping. Mme Cheron dies (due to Montoni's cruelty), leaving her property to Emily. Emily escapes from \\
Montoni's castle (Udolpho) with the help of an ex-suitor and some servants. She makes friends. She finds \\
Valancourt, who has lost all his money. Montoni dies a deservedly awful death (elsewhere). Emily takes over \\
her aunt's estate, and marries a penitent Valancourt. Multiple other storylines are intertwined with the main \\
plot: they include a mysterious nun, young people who befriend Emily, and another uncle (Quesnel). \\
\hline Northanger Abbey \\
\hline Catherine Moreland, an imaginative young girl from a large family, is invited to Bath by family friends. \\
There she makes friends with Isabella Thorpe, and begins to fall in love with Henry Tilney. Catherine's \\
brother, James, pairs up with Isabella. Catherine is not interested in pairing up with Isabella's brother John. \\
She forms a friendship with Henry Tilney and his sister Eleanor, and is invited to their home, the Abbey. The \\
Thorpes, who believe that the Morelands are rich, attempt to distract Catherine. Isabella and James become \\
engaged. At the Abbey Catherine, who has been reading Udolpho, is welcomed and treated well, but she \\
becomes suspicious of General Tilney and assumes that Mrs. Tilney's recent death was not a natural one. \\
Eventually, Catherine's gothic imaginings are laid to rest, and Henry scolds her for them. Isabella dumps \\
James in search of a better option. One day Catherine is suddenly sent home from the Abbey with no clear \\
explanation. (It turns out that her lack of riches had been discovered by General Tilney, who no longer \\
wished her to marry Henry.) Henry visits Catherine and explains. When Eleanor marries money, the General \\
relents and Henry and Catherine are allowed to marry. \\
\hline
\end{tabular}

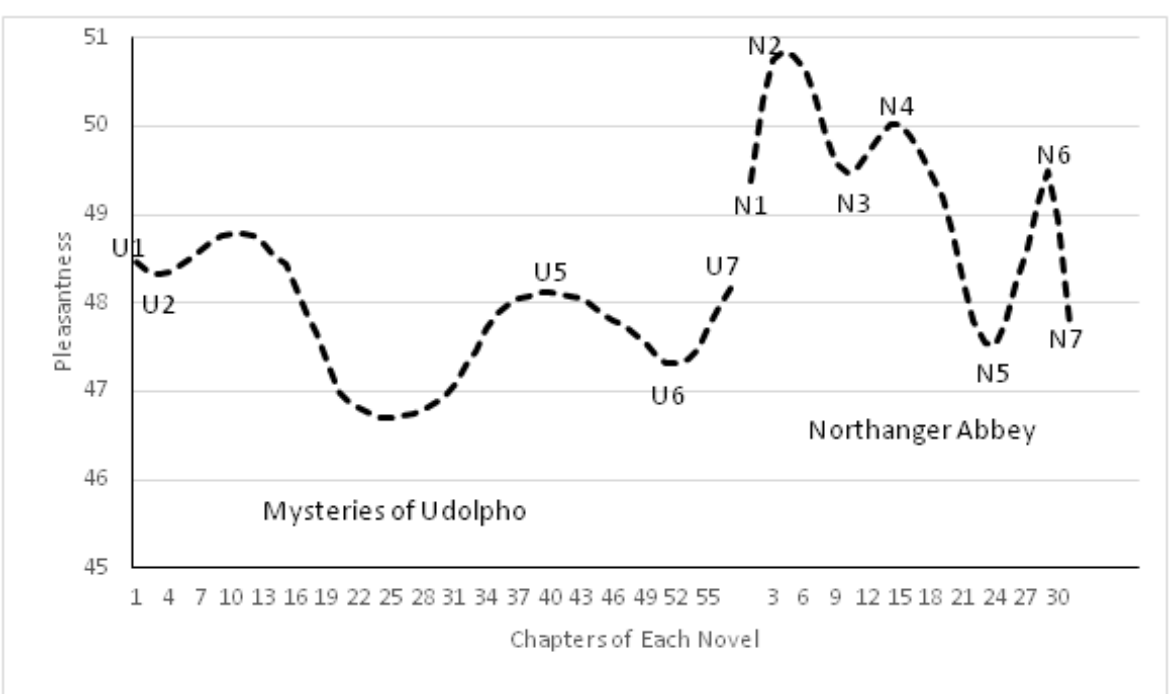

Figure2. Plots for Mysteries of Udolpho and Northanger Abbey modeled by $6^{\text {th }}$ order polynomial regressions predicting pleasantness and plotted as a function of chapter

U1-Beginning of Udolpho.

U1-U2 - Things get worse as Emily's mother dies.

U2-U3 - Things get better as Emily travels with her father and meets Valancourt.

U3-U4 - Things get worse as Emily's father dies and Emily is isolated at Castle Udolpho at the mercy of Montoni.

U4-U5 - Things get better as Emily escapes with the help of friends.

U5-U6 - Things get worse after Valancourt returns but fails to win Emily's favour, and Emily returns to the castle.

U6-U7 - Things get better as the story moves to a happy ending; Emily gains an inheritance and marries Valancourt.

N1 - Beginning of Northanger.

N1-N2 - Things get better as Catherine travels to Bath and makes new friends.

N2-N3 - Things get worse as Catherine is interested in Henry, but worries that her affection is not returned. 
N3-N4 - Things get better as Catherine makes friends with Henry and his sister Eleanor.

N4-N5 - Things get worse as Catherine is invited to the Abbey and her suspicions grow and grow.

N5-N6 - Things get better as Catherine's suspicions prove groundless, but she is sent home.

N6-N7 - Things get worse: it seems that Henry and Catherine cannot get married, but in the end (abruptly, and purely by chance) they can.

The plots in Figure 2 involve various turning-points - points where extremes of emotionality are reached and the emotional progress of the plot changes direction. These turning-points are numbered consecutively for each novel in Figure 2. The movement of the plot is described at the bottom of Figure 2 in terms of changes in the pleasantness of language between pairs of points within each novel. The phrase "things get better" indicates a rising pleasantness between two points and the phrase "things get worse" a falling pleasantness. For example, the pair of points U2 and U3 is from Udolpho: language between these two points shows a rising pleasantness as Emily recovers from her mother's death, travels with her father, and meets Valancourt, her love interest. Points N4 and N5 are from Northanger: pleasantness falls sharply between these points as Catherine, who goes to the Abbey as a guest, allows her imagination to run wild, and begins to suspect her host of murder. Each novel has a nadir, or low point for pleasantness. For Udolpho, this nadir is at U4. Emily here is afraid for her virtue and her life, and suspects her uncle Montoni of murdering her aunt. For Northanger, the nadir is at N5, where Catherine, after reading Udolpho, allows her suspicions free reign and desperately attempts to examine the late Mrs. Tilney's room.

Udolpho and Northanger differ noticeably in terms of the emotional character of their endings. Udolpho has a happy ending whose pleasantness score (48.17) is similar to the one characterizing Emily's happy life at the beginning of the novel (48.57). The happiness of the ending is evident in the rise in pleasantness between U6 and U7. Northanger, on the other hand, has a sad ending whose pleasantness score (47.74) is well below the pleasantness of the first chapter of the novel (49.38) and quite close to that at the nadir of the novel (47.55): the decrease in pleasantness between N6 and N7 represents the unhappy ending. As well, the rate at which pleasantness changes is different in the two novels. This can be seen in the angle of inflection at each change point; angles are sharper for Northanger than they are for Udolpho. The plot for Udolpho sails grandly across the less pleasant region of the space in Figure 2: although it changes direction, it does so smoothly and gradually. The plot for Northanger tacks rather wildly across the more pleasant region of the space, changing direction sharply several times with emotion going from more to less pleasant (or vice versa) relatively quickly.

\section{Northanger Abbey: An Unexpected Result}

The findings reported in this section were not central to the original purpose of the research: they arose, instead, from information gathered with reference to Northanger Abbey that prompted further analysis. Two authors pointed strongly to something unusual in the structure of the novel. Stéphane (1984, p. 19) noted that the attempt to parody Udolpho and the gothic genre by introducing an isolated mansion, a distinguishing characteristic of the genre, might have been an afterthought for Austen. Stéphane based this conclusion on the fact that references to Northanger Abbey (the building) do not occur until the second half of the novel, which had been significantly re-worked between the novel's original writing date and its publication. Catherine Moreland, the heroine, is invited to visit Northanger Abbey in the $17^{\text {th }}$ of 31 chapters, and this the first readers hear of the gothic edifice. Direct references to Udolpho (Radcliffe's work) and its author are found scattered between chapters 1 and 14 of the novel while direct references to Northanger (the building) only occur from chapter 17 onwards. ${ }^{7}$ References to "novel/s" are also limited to the early chapters. A single reference to Mrs. Radcliffe is found in chapter 25 where a chastened Catherine vows to take a more realistic - and less gothic - view of the world around her. There is no overlap between the two sets of references (to the novel, to the building) suggesting that there is an early "Udolpho Reference" segment of Austen's novel and a later and discrete "Udolpho Parody" segment. The transition is located between N4 and N5 in Figure 2.

A rather abrupt change in style between early and later portions of Austen's novel was addressed by Emden (1968, p. 97), who devoted some time to building a theory of the composition of Northanger Abbey which he believes took place in two distinct stages:

\footnotetext{
7 The "Find" command of Word ${ }^{\circledR}$ was employed to ascertain this.
} 
"Clear evidence is to be found of similarities between features in her [Austen's] juvenilia and features of those portions of the book which include satire of the silly sentimental novel and of contemporary manners [earlier Udolpho Reference stage]. Contrariwise, there is little, if any, sign of influence of her juvenilia on those parts, about a quarter of the whole, which aim at burlesquing the horror-novel [later Udolpho Parody stage]. Moreover, the behaviour of the heroine in the burlesque passages and that in the light satire of the main portion are incompatible".

Emden (1968) suggests that the writing of the first part of the Northanger Abbey pre-dated the publication of Udolpho and that all references to this novel, as well as the burlesque which constitutes the ending section, must have been added at a later date.

Emotional differences between the two segments of the novel support the argument of an interrupted composition. The early "Udolpho Reference" segment of Austen's novel (chapters 1-16) is the more pleasant of the two (see Figure 2). The less pleasant "Udolpho Parody" segment (chapters 17-31) is a more direct attempt at mockery - both of the original genre and of its readers. ${ }^{8}$ In the older Udolpho Reference segment of the novel, Austen's language was more positive in nature but when she moved instead to a more burlesque form of genre parody (by introducing the Abbey) it became less pleasant and more like that of the novel being parodied. The earlier "Udolpho Reference" section of the novel addresses the social interactions of a foolish young woman who reads gothic novels, but the "crises" in this section are social - not gothic - ones. Catherine does not know if Henry returns her romantic interest. Catherine is torn between spending time with Henry and his sister Eleanor as opposed to spending time with her first new friend in Bath, Isabella, and Isabella's brother. The later "Udolpho Parody" section of the novel contains recognizable gothic elements, as symbolized by the Abbey itself, by Henry's frightening father, the General, and by the "mysterious" death of the General's wife. The crisis in this section is located in the chapters where Catherine attempts to search the late Mrs. Tilney's room to find proof of this lady's supposed murder.

\section{CONCLUSION}

As can be seen from the summary in Table 3, The Mysteries of Udolpho and Northanger Abbey differ from one another in many ways. They differ in stylistic terms, they differ in emotional terms, and they differ in plot structure. Udolpho is more unpleasant, more passive, and more concrete in its language than Northanger. Udolpho has a happy ending while Northanger does not. The pleasantness level of the text changes gradually in Udolpho and abruptly in Northanger. These emotional differences are likely the outcome of differences between the styles of gothic genre and parody as well as differences between the styles of writing favoured by each author.

Table3: An overview of the differences between the two novels

\begin{tabular}{|l|l|l|}
\hline Characteristic & Mysteries of Udolpho & Northanger Abbey \\
\hline Writing Style & & \\
\hline Overall Length & Longer & Shorter \\
\hline Chapter Length & Longer & Shorter \\
\hline Sentence Length & Longer & Shorter \\
\hline Emotion and Imagery & & \\
\hline Pleasantness & More unpleasant & More pleasant \\
\hline Activation & More passive & More active \\
\hline Imagery & More concrete & More abstract \\
\hline Plot Shape & & \\
\hline Ending & Happy (rising pleasantness) & Sad (falling pleasantness) \\
\hline Rate of Change in Emotion & More Leisurely & More Abrupt \\
\hline
\end{tabular}

There are also clearly established differences between portions of Northanger Abbey, specifically between an earlier portion (chapters 1-16) and a later one (chapters 17-31). The early portion is more pleasant and more active than the later one. It refers frequently to Mrs. Radcliffe's Udolpho, while the

\footnotetext{
${ }^{8}$ According to t tests, the "Udolpho Reference" section of Austen's novel (chapters 1-16) is both more pleasant (50.06 versus 48.42) and more active (49.57 versus 48.34) than the "Udolpho Parody" section (chapters 17-31, $\mathrm{p}<.001)$.
} 
later portion does not. Instead, the later portion deploys its own gothic symbolism (the Abbey, a seemingly mysterious death, the threatening figure of the General). It is possible that Austen, having recovered the rights to her early work from a publisher, embellished the existing work with a new burlesque ending. The earlier portion of the novel gently and cheerfully pokes fun at gothic novels, while the later portion specifically parodies them, and does so in grimmer emotional terms. Observed differences suggest that a theory of composition involving two distinct stages is essential. Something changed in the middle of Austen's novel, but there is not enough evidence to allow us to conclude decisively whether the two-part composition described here (or either of the ones suggested by Emden, 1968, or Stéphane, 1984) are exactly what took place. Austen had not just one connexion to the gothic but two different connexions, each epitomized in one portion of her novel. She lovingly chided gothic novels and their readers (early portion) but she also unkindly mocked them (later portion).

\section{REFERENCES}

[1] Benét's Reader's Encyclopedia (1987) $3^{\text {rd }}$ edition, NY, NY, Harper \& Rowe.

[2] Emden, Cecil, S. (1968) The composition of Northanger Abbey. The Review of English Studies, 19, 279287.

[3] Freeman, R. (1963) Parody as a literary form: George Herbert and Wilfred Owen. Essays in Criticism: A Quarterly Journal of Literary Criticism. 13, 307-322.

[4] Hannoosh, M. (1988) The reflexive function of parody. Comparative Literature, 41, 113-127.

[5] Howard, J. (2001) Introduction to Mysteries of Udolpho by A. Radcliffe, London, UK, Penguin.

[6] Lenckos, E. (2010) From sublime abbey to picturesque parsonage: the aesthetics of Northanger Abbey and The Mysteries of Udolpho. Persuasions, 32, 105-114.

[7] Rehn, A. (2014) "Hastening together to perfect felicity": teaching the British gothic tradition through parody and role-playing. Persuasions, vol. 34.

[8] Skinner, K. (2013) "Horrid" gothicism: Austen's Northanger Abbey. The Explicator, 71, 229-232.

[9] Stéphane, N. (1984) Un parodie du roman noir: Northanger Abbey de Jane Austen. Europe, 62;659, 19-28.

[10] Wallace, T. G. (1988) "Northanger Abbey" and the limits of parody. Studies in the Novel, 20, 262-273.

[11] Whissell, C. (2009) Using the revised Dictionary of Affect in Language to quantify the emotional undertones of samples of natural language. Psychological Reports, 105, 1-13.

[12] Whissell, C. (2017) Event segmentation as an explanation for the seemingly inconsistent structure of Wordsworth's "Prelude". International Journal of Interdisciplinary Cultural Studies, Volume 12, Issue 1.

Citation: Cynthia Whissell. "Northanger Abbey: Jane Austen's Connexion with Ann Radcliffe and the Gothic". International Journal on Studies in English Language and Literature (IJSELL), vol 5, no. 9, 2017, pp. 51-59. doi:http://dx.doi.org/10.20431/2347-3134.0509006.

Copyright: (0) 2017 Authors. This is an open-access article distributed under the terms of the Creative Commons Attribution License, which permits unrestricted use, distribution, and reproduction in any medium, provided the original author and source are credited. 